\section{Election of President}

\section{Notice to Fellows and Members}

Fellows and Members are reminded of their rights under the Bye-laws and Regulations, as follows:

\section{Bye-law XI}

The President shall be elected annually from amongst the Fellows.

\section{Regulation XI}

(1) As soon as may be practicable after the first day of January in any year the Council shall hold a nomination meeting and shall. . nominate not less than one candidate and not more than three candidates...

(2) Between the first day of January in any year and the date which is four clear weeks after the nomination meeting of the Council, written

\section{Election to the Fellowship}

Candidates for election to the Fellowship are considered annually by the Court of Electors.

Candidates may not make a personal approach to the College for election, but must be nominated by two sponsors, who must be Fellows of the College.

Sponsors should apply in writing to the Registrar for the relevant forms. Completed nominations should be submitted to the Registrar by 30 September in any year, for considerations by the Court at its meeting the following February.

\section{Eligibility of nominees}

a. Candidates must either be Members of the College by Examination of more than five years standing, or Members who have been granted exemption from Examination. nominations, accompanied in each case by the nominees' written consent to stand for election, may be lodged with the Registrar, provided that each such nomination is supported in writing by not less than twelve Members of the College who are not members of the Council.

(3) An election by ballot shall be held in accordance with the provisions of the Regulations.

The nominating meeting of the Council will be held on 17 January 1989 and the last date for receiving nominations under (2) above will therefore be 14 February 1989. Dr J. L. T. Birley is in his second year of office as President and is therefore eligible to serve one further year.

\title{
College Appeal Fund
}

We would like to make it clear that the list of contributors to the Appeal Fund which appeared in the November 1988 issue of the Psychiatric Bulletin gave the names of all new contributors to the Fund, who had made donations since July 1987, when b. The Fellowship is ordinarily awarded to a Member for unusual distinction in teaching, research, and/or administrative ability, or for exceptional service to patients, especially where the supporting services have been inadequate. Sponsors are therefore asked to indicate any factors which go beyond the carrying out of consultant or academics duties by the candidates of their choice.

All sponsors and all successful candidates will be notified by letter of the decision of the Court of Electors.

Individuals elected to the Fellowship become entitled to use the designation FRCPsych after they have paid the prescribed registration fee. we last published a list of contributors in the Bulletin.

We apologise to Dr S. Sungum-Paliwal, whose name was incorrectly spelt (Psychiatric Bulletin, 12, 506). 